\title{
A new combination of transcription factors increases the harvesting efficiency of pacemaker-like cells
}

\author{
JIAN ZHANG ${ }^{1-3}$ and CONGXIN HUANG ${ }^{1-3}$ \\ ${ }^{1}$ Department of Cardiology, Renmin Hospital of Wuhan University; ${ }^{2}$ Cardiovascular Research Institute, \\ Wuhan University; ${ }^{3}$ Hubei Key Laboratory of Cardiology, Wuhan, Hubei 430060, P.R. China
}

Received July 4, 2018; Accepted February 1, 2019

DOI: $10.3892 / \mathrm{mmr} .2019 .10012$

\begin{abstract}
Biological pacemakers that combine cell-based and gene-based therapies are a promising treatment for sick sinus syndrome or severe atrioventricular block. The current study aimed to induce differentiation of adipose tissue-derived stem cells (ADSCs) into cardiac pacemaker cells through co-expression of the transcription factors insulin gene enhancer binding protein 1 (ISL-1) and T-box 18 (Tbx18). ADSCs were transfected with green fluorescent protein, ISL-1, Tbx 18 or ISL-1+Tbx18 fluorescent protein lentiviral vectors, and subsequently co-cultured with neonatal rat ventricular cardiomyocytes in vitro for 7 days. The potential for regulating the differentiation of ADSCs into pacemaker-like cells was evaluated by cell morphology, beating rate, reverse transcription-quantitative polymerase chain reaction, western blotting, immunofluorescence and electrophysiological activity. ADSCs were successfully transformed into spontaneously beating cells that exhibited a behavior similar to that of co-cultured pacemaker cells. This effect was significantly increased in the combined ISL- 1 and Tbx18 group. These results provide a potential strategy for enriching the cardiac pacemaker cell population from ADSCs.
\end{abstract}

\section{Introduction}

A biological pacemaker, which may be created via cell therapy or gene therapy, is able to restore cardiac pacing and conduction function for patients with bradyarrhythmia (1-3). Cell-based and gene-based approaches have limitations: Gene therapies may cause gene mutations and are dependent on the function of the vectors carrying the genes, while cell therapies carry the risk of immunosuppression and tumor formation from their implantation site. Hybrid treatments, which combine gene and

Correspondence to: Professor Congxin Huang, Department of Cardiology, Renmin Hospital of Wuhan University, 238 Jiefang Road, Wuchang, Wuhan, Hubei 430060, P.R. China

E-mail: huangcongxin@vip.163.com

Key words: biological pacing, adipose tissue-derived stem cells, insulin gene enhancer binding protein 1, T-box 18, pacemaker cells cell therapy to create biological pacemakers, have attracted more interest in recent years (4-6). Stem cells are the most common source for deriving pacemaker cells, since they have great potential for proliferation and pluripotent differentiation. Adipose tissue-derived stem cells (ADSCs) have become promising candidate cells for biological pacemakers due to their accessibility, high harvesting efficiency and myocardial differentiation potential $(7,8)$.

The sinoatrial node (SAN) is a complex structure, which is regulated by multiple factors and multiple mechanisms. Transcription factors serve an important role in the formation and development of the SAN (9-11). T-box 18 (Tbx18) begins to be expressed during the formation of the sinus horn myocardium after embryonic day (E) 9.5, and its expression is maintained. It has been proposed that Tbx 18 is essential for the formation and differentiation of the mesenchyme of the sinus horn. Between E9.5 and E10.5, insulin gene enhancer binding protein 1 (ISL-1), which encodes a LIM-domain homeodomain transcription factor, becomes expressed in the dorsal mesenchyme (12). Although the Tbx18-positive and ISL-1-positive progenitor cells remain spatially and temporally separate during heart tube elongation, there exists a small area of overlapping expression from E8.5 at the right lateral side of the inflow tract. This Tbx18/ISL-1 co-expressing area will form the SAN of the heart (13). This raises the possibility that co-expression of ISL-1 and Tbx 18 in ADSCs may induce reactivation of the embryonic development pathway of the SAN. The current study aimed to explore whether the combination of ISL-1 and Tbx 18 was sufficient to successfully induce ADSCs to differentiate into pacemaker cells in order build a new biological pacemaker in vitro.

\section{Materials and methods}

Isolation and culture of ADSCs. All experimental procedures were conducted in accordance with the Institutional Guidelines for the Care and Use of Laboratory Animals at Wuhan University (Wuhan, China) and conformed to the National Institutes of Health (NIH) Guide for the Care and Use of Laboratory Animals (NIH Publications, no. 8023, revised 1978; Bethesda, MD, USA). The present study was approved by the Experimental Animal Committee of Wuhan University (no. WDRM20171015; Wuhan, China). Adult male Sprague-Dawley (SD) rats $(\mathrm{n}=4$; age, 3-4 weeks; weight, 
40-80 g) were purchased from the Center for Disease Control and Prevention of Hubei Province (SCX 20150018; Hubei, China). All rats were housed at a temperature of $24^{\circ} \mathrm{C}$, relative humidity of $60 \%$ and change of air 10 times/h prior to being sacrificed by cervical dislocation. ADSCs were obtained using a previously described method with modifications (14). Briefly, SD rat inguinal adipose tissue was digested in a solution containing $0.1 \%$ (w/v) collagenase type I (Sigma-Aldrich; Merck KGaA, Darmstadt, Germany) at $37^{\circ} \mathrm{C}$ for 45 min with gentle agitation. Following filtering and centrifugation at $1,000 \mathrm{x} \mathrm{g}$ for $10 \mathrm{~min}$ at room temperature, the supernatant was discarded. The pellet was re-suspended in Dulbecco's modified Eagle's medium (DMEM)/F12 (Gibco; Thermo Fisher Scientific, Inc., Waltham, MA, USA), supplemented with $10 \%$ fetal bovine serum (FBS; Gibco; Thermo Fisher Scientific, Inc., Waltham, MA, USA) and $1 \%$ penicillin/streptomycin (Invitrogen; Thermo Fisher Scientific, Inc.). Cells were seeded in 6-well plates at a cell density of $3 \times 10^{5}$ cells $/ \mathrm{ml}$ (Corning, Inc., Corning, NY, USA) and incubated at $37^{\circ} \mathrm{C}$ with a $5 \% \mathrm{CO}_{2}$ atmosphere. The medium was changed every 2 days.

Transduction of human ISL-1 and Tbx18 lentiviral vectors. Once ADSCs reached 80-90\% confluence, adherent cells were detached with $0.25 \%$ trypsin (Genom, Hangzhou, China; www.genom.com.cn) solution and passaged. Cells of passages 3-5 were used for all subsequent experiments. Lentiviruses overexpressing ISL-1 (Ubi-MCS-ISL-1-3flag-S V40-mCherry; GeneChem, Inc., Shanghai, China) or Tbx18 (pHBLV-CMV-MCS-Tbx18-3flag-EF1-ZSgreen-puro; Hanbio Biotechnology, Co., Ltd., Shanghai, China) and $8 \mu \mathrm{g} / \mathrm{ml}$ polybrene were mixed together and added to the culture medium of cells at different multiplicity of infection (MOI) values (MOI=0, $20,50,80$ and 100) when they reached $30 \%$ confluence. The culture medium was replaced following culturing at $37^{\circ} \mathrm{C}$ in $5 \% \mathrm{CO}_{2}$ for 8-12 h. Fluorescence microscopy (BX51 systems; Olympus Corporation, Tokyo, Japan) was used to observe the expression of fluorescent protein after $48 \mathrm{~h}$. The percentage of fluorescent protein-positive cells was detected by recording the number of fluorescent cells in at least five different random fields under fluorescence microscopy. A total of 7 days post-infection, cells were harvested for evaluation of hISL-1 and hTBX18 expression by reverse transcription-quantitative polymerase chain reaction (RT-qPCR).

Isolation and culture of neonatal rat ventricular cardiomyocytes (NRVMs) and co-culture systems. Primary NRVMs were isolated from 1-3 day-old newborn SD rats $(n=100$; weight: 5-15 g), which were purchased from the Center for Disease Control and Prevention of Hubei Province (SCX 20150018; Hubei, China) and sacrificed by cervical dislocation. Firstly, neonatal rat heart tissues were digested with $0.125 \%$ trypsin at $37^{\circ} \mathrm{C}$ for $10 \mathrm{~min}$. Subsequently, the precipitate was repeatedly digested with a solution containing $0.125 \%$ trypsin and $0.08 \%$ collagenase II (Biosharp, Wuhan, China) 5-8 times, at $37^{\circ} \mathrm{C}$, for $5 \mathrm{~min}$. Subsequent to being filtered and centrifuged at $1,000 \mathrm{x} \mathrm{g}$ for $10 \mathrm{~min}$, the supernatant was discarded. The pellets were re-suspended and seeded in 6-well plates at a cell density of $5 \times 10^{5}$ cells $/ \mathrm{ml}$ with fresh DMEM/F-12 supplemented with $15 \%$ FBS and $1 \%$ penicillin/streptomycin. The harvested NRVMs were purified via their differential adhesion time to isolate the cardiomyocytes from the fibroblasts and $0.1 \mathrm{mmol} / \mathrm{l}$ bromodeoxyuridine (Sigma-Aldrich; Merck KGaA) to inhibit the mitosis of fibroblasts (15). For co-culture experiments, ADSCs ( $1 \times 10^{5}$ cells) and NRVMs ( $1 \times 10^{6}$ cells) were mixed and plated at a ratio of 1:10 onto the 6 -well plates $(16,17)$. NRVMs without any treatment were designated the Blank group and ADSCs transduced with green fluorescent protein (GFP) the GFP group. The complete culture medium was replaced every 2 days.

$R T$-qPCR. Total cellular RNA was extracted from the co-culture systems after 7 days using TRIzol ${ }^{\circledR}$ (Invitrogen; Thermo Fisher Scientific, Inc.), according to the manufacturer's protocol. Isolated RNA was converted into cDNA using the First Strand cDNA Synthesis kit (Takara Bio, Inc., Otsu, Japan) in a $15 \mu 1$ mixture as follows: $25^{\circ} \mathrm{C}$ for $5 \mathrm{~min}$, $50^{\circ} \mathrm{C}$ for $15 \mathrm{~min}, 85^{\circ} \mathrm{C}$ for $5 \mathrm{~min}$ and $4^{\circ} \mathrm{C}$ for $10 \mathrm{~min}$. All primers (Table I) for PCR amplification were synthesized by Invitrogen (Thermo Fisher Scientific, Inc.). RT-qPCR was performed with standard SYBR ${ }^{\circledR}$ Premix Ex Taq ${ }^{\mathrm{TM}}$ (Takara Bio, Inc.) on a StepOne ${ }^{\mathrm{TM}}$ Real-Time PCR (Thermo Fisher Scientific, Inc.) instrument as follows: Pre-denaturation at $95^{\circ} \mathrm{C}$ for $5 \mathrm{~min}$, denaturation at $95^{\circ} \mathrm{C}$ for $30 \mathrm{sec}$, annealing at $60^{\circ} \mathrm{C}$ for $20 \mathrm{sec}$, and a final extension at $60^{\circ} \mathrm{C}$, a total of 40 cycles. The dissolution curve was from $60-95^{\circ} \mathrm{C}$ and the temperature was raised by $1^{\circ} \mathrm{C}$ per $20 \mathrm{sec}$. Relative gene expression was calculated using the $2^{-\Delta \Delta \mathrm{Cq}}$ method (18) following normalization to GAPDH expression. To ensure accuracy, all results were repeated $\geq 3$ times.

Western blotting analysis. Cells were harvested using radioimmunoprecipitation assay lysis buffer (Aspentech, Houston, America). Protein concentrations were determined with a bicinchoninic acid protein kit, according to the manufacturer's instructions. Then, 5\% of concentration gel and $10 \%$ of separation gel were chosen and the protein samples (40 $\mu \mathrm{g}$ protein/lane) were mixed with $5 \mathrm{X}$ SDS-PAGE buffer (Aspentech) in a water bath at $95-100^{\circ} \mathrm{C}$ for $5 \mathrm{~min}$, prior to being transferred to a polyvinylidene fluoride membrane. Following blocking with 5\% nonfat milk in tris-buffered saline containing $0.05 \%$ Tween-20, the membranes were incubated overnight at $4^{\circ} \mathrm{C}$ with primary antibodies against potassium/sodium hyperpolarization-activated cyclic nucleotide-gated channel 4 (HCN4; 1:1,000; cat. no. ab32675; Abcam, Cambridge, MA, USA), connexin 43 (Cx43; 1:3,000; cat. no. ab11370; Abcam) and connexin 45 (Cx45; 1:1,000; cat. no. AF5108; Affinity Biosciences, Cincinnati, $\mathrm{OH}, \mathrm{USA}$ ). The membranes were incubated for $30 \mathrm{~min}$ at room temperature with corresponding secondary antibodies: Horseradish peroxidase (HRP)-conjugated goat anti-rat (1:10,000, cat. no. AS1093; Aspen Biological) or HRP-conjugated goat anti-rabbit (1:10,000, cat. no. AS1107; Aspentech). Visualization was performed using an enhanced chemiluminescence detection kit (Aspentech), according to the manufacturer's recommendations. The level of GAPDH (ab37168, Abcam) was used to normalize the signal intensities. The image collection and densitometry analyses were performed with Quantity One analysis software (AlphaEaseFC V; ProteinSimple, San Jose, CA, USA). Experiments were performed $\geq 3$ times to verify the results. 
Table I. Polymerase chain reaction primers used in this study.

\begin{tabular}{|c|c|c|}
\hline Gene & Primer sequences $\left(5^{\prime}-3^{\prime}\right)$ & $\begin{array}{l}\text { Product } \\
\text { size (bp) }\end{array}$ \\
\hline H-ISL-1 & & 181 \\
\hline Forward & GCGGCAATCAGATTCACGAT & \\
\hline Reverse & GCGCATTTGATCCCGTACAA & \\
\hline H-Tbx 18 & & 173 \\
\hline Forward & TCCAAGGTACTGGGAATGGC & \\
\hline Reverse & TGTGCTGTATCGGTTGAGGG & \\
\hline R-HCN4 & & 300 \\
\hline Forward & GCATCCACGACTACTACGAAC & \\
\hline Reverse & TCTCCTTGTTGCCCTTAGTG & \\
\hline R-cTnT & & 202 \\
\hline Forward & GCAGGCTCTTCATGCCCAACT & \\
\hline Reverse & CGCTCTGCCCGACGCTTTT & \\
\hline $\mathrm{R}-\mathrm{Tbx} 3$ & & 168 \\
\hline Forward & TTACAGCCCGTATTCCATCCC & \\
\hline Reverse & CGGCTATTCAGTTCCGACCC & \\
\hline R-Nkx2.5 & & 248 \\
\hline Forward & ACGCССTTCTCAGTCAAAGA & \\
\hline Reverse & TAAAATGTAGGGGCGGTTGG & \\
\hline $\mathrm{R}-\mathrm{Cx} 43$ & & 242 \\
\hline Forward & GGCAAGGTGAAAATGAGGGG & \\
\hline Reverse & AAAGCGAGAGACACCAAGGA & \\
\hline $\mathrm{R}-\mathrm{Cx} 45$ & & 112 \\
\hline Forward & TTCTGATAATGTATGGTGTC & \\
\hline Reverse & AGTTCCCTCCTTTTACTGTT & \\
\hline R-GAPDH & & 253 \\
\hline Forward & ACAGCAACAGGGTGGTGGAC & \\
\hline Reverse & TTTGAGGGTGCAGCGAACTT & \\
\hline
\end{tabular}

H-ISL-1, human insulin gene enhancer binding protein 1; H-Tbx18, human T-box 18; R-HCN4, rat hyperpolarization-activated cyclic nucleotide-gated potassium channel 4; R-cTnT, rat cardiac troponin T; R-Tbx3, rat T-box 3; R-Nkx2.5, rat homeobox protein Nkx-2.5; $\mathrm{R}-\mathrm{Cx} 43$, rat connexin 43; R-Cx45, rat connexin 45.

Immunofluorescence. Cells were fixed with $4 \%$ paraformaldehyde for $15 \mathrm{~min}$ at room temperature. Following three washes with PBS for $5 \mathrm{~min}$, cells were treated with $0.2 \%$ Triton (Sigma-Aldrich; Merck KGaA) for $15 \mathrm{~min}$. The cells were incubated with the primary antibodies against anti-cardiac troponin T (cTnT; cat. no. ab8295; Abcam) or HCN4 (cat. no. ab32675; Abcam) overnight at $4^{\circ} \mathrm{C}$, followed by incubation with goat anti-mouse Alexa Fluor ${ }^{\circledR} 647$ (cat no. A0473; Beyotime Institute of Biotechnology, Haimen, China) or goat anti-rat Alexa Fluor ${ }^{\circledR} 647$ (cat. no. ab150167; Abcam) secondary antibodies for $50 \mathrm{~min}$ at room temperature. DAPI solution was used to stain the nuclei as above. Fluorescent images were obtained with a Leica-LCS-SP8-STED confocal laser-scanning microscopy (Leica Microsystems $\mathrm{GmbH}$, Wetzlar, Germany) and were redistributed using confocal analysis software (LAS-AF-Lite 2.6.1; Leica Microsystems
$\mathrm{GmbH})$. Images were obtained from three random visual fields in three different samples in order to assess the levels of cTnT and HCN4 expression.

Electrophysiological recordings. To examine the electrophysiological properties of individual cells derived from ADSCs, whole cell patch-clamp technique was used to record the funny current $\left(\mathrm{I}_{\mathrm{f}}\right)$. The Axon patch-clamp amplifier 700B (Molecular Devices, LLC, Sunnyvale, CA, USA), digital 700AD/DA converter and 6.0.4 pClamp (both from Axon Instruments; Molecular Devices, LLC) were used for recording and analyzing the data. Following co-culture for 7 days, the cells were incubated with $180 \mu \mathrm{mol} / 12$-aminoethoxydiphenyl borate (Sigma-Aldrich; Merck KGaA) for 15 min to block intercellular electrical conduction. Cells were perfused with a normal Tyrode's solution containing $\mathrm{NaCl} 135 \mathrm{mmol} / \mathrm{l}, \mathrm{KCl} 5.4 \mathrm{mmol} / \mathrm{l}$, $\mathrm{CaCl}_{2} 1.8 \mathrm{mmol} / \mathrm{l}, \mathrm{MgCl}_{2} 1 \mathrm{mmol} / \mathrm{l}$, glucose $10 \mathrm{mmol} / \mathrm{l}, \mathrm{Bacl}_{2}$ $1 \mathrm{mmol} / 1$ and 4-(2-hydroxyethyl)-1-piperazineethanesulfonic acid (HEPES) $10 \mathrm{mmol} / \mathrm{l}(\mathrm{pH}=7.4)$ with $\mathrm{NaOH}$, while recordings were under way. The pipette solution contained: $\mathrm{KCl}$ $120 \mathrm{mmol} / \mathrm{l}, \mathrm{Cacl}_{2} 1 \mathrm{mmol} / \mathrm{l}, \mathrm{MgCl}_{2} 5 \mathrm{mmol} / 1$, HEPES $10 \mathrm{mmol} / \mathrm{l}$, EGTA $10 \mathrm{mmol} / \mathrm{l}(\mathrm{pH}=7.35)$ with $\mathrm{KOH}$. The impedance of the fluid filled electrode was 5 to $7 \mathrm{M} \Omega$. The Clampex version 6.0 software was used to collect data. The sampling frequency was $10 \mathrm{kHz}$ and the filtering rate was $5 \mathrm{kHz}$. Holding potential was set at $-30 \mathrm{mV}$, and a set of hyperpolarizing voltage steps, ranging between $-140 \mathrm{mV}$ and $-40 \mathrm{mV}$ for $1.5 \mathrm{sec}$ with $20 \mathrm{mV}$ increments, was applied to elicit $\mathrm{I}_{\mathrm{f}}$. $\mathrm{CsCl}(4 \mathrm{mmol} / \mathrm{l})$ was administered to detect alterations in the $\mathrm{I}_{\mathrm{f}}$.

Statistical analysis. All data are expressed as the mean \pm standard deviation. Significant differences among multiple groups were analyzed by performing one-way analysis of variance followed by Tukey's multiple comparison tests. Statistical analyses were performed using SPSS 19.0 software (IBM Corp., Armonk, NY, USA). P<0.05 was considered to indicate a statistically significant difference.

\section{Results}

Optimum MOI value for transfection and expression of the human ISL-1 and Tbx18 genes. Primary ADSCs became adherent with an irregular spindle shape and reached 80-90\% confluence following culture for 5-7 days. Following passaging, ADSCs were able to reach $\sim 90 \%$ confluence in a homogenous spindle-like fashion within 2-3 days. At 2 days post-transfection, it was observed that infected ADSCs exhibited red or green fluorescence or both, depending on whether the cultures were transfected with ISL-1, Tbx18 or both, respectively (Fig. 1A, B and $\mathrm{C}$, respectively). The number of fluorescent cells in at least 5 different random fields was observed under fluorescence microscopy. The fluorescence intensity was increased at higher MOI values (Fig. 1D). When the MOI value was 20, comparatively few cells were observed. At a MOI value of 50, the percentage of fluorescent cells was $83.2 \pm 5.8 \%$ (ISL-1 group) or $62.7 \pm 6.7 \%$ (Tbx18 group). When the MOI value was 80 , the percentage of fluorescent cells was $89.7 \pm 6.3 \%$ (ISL-1 group) or $84.7 \pm 4.9 \%$ (Tbx18 group). A small number of fluorescent cells appeared as roundish cells with vacuoles in the cytoplasm, and gradually began to 

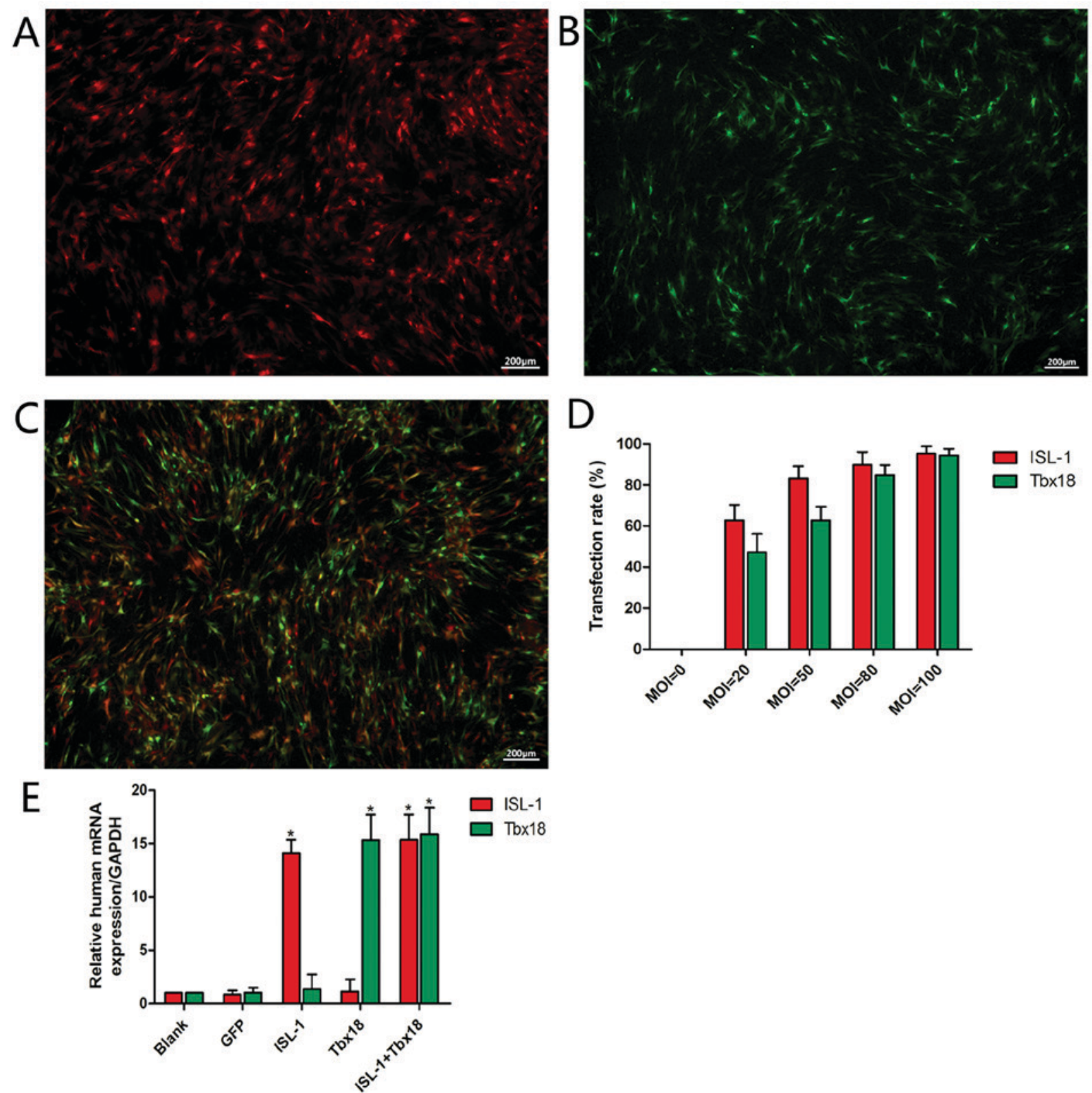

Figure 1. Transfection rate, transfected gene expression and culture conditions. (A) ISL-1-ADSCs observed at $48 \mathrm{~h}$ under a fluorescence microscope (magnification, $\mathrm{x} 40$ ). (B) Tbx18-ADSCs observed at $48 \mathrm{~h}$ under a fluorescence microscope (magnification, $\mathrm{x} 40$ ). (C) ISL-1+Tbx18-ADSCs observed at $48 \mathrm{~h}$ under a fluorescence microscope (magnification, x40). (D) Transfection rate of different MOI values. (E) Expression of human ISL-1mRNA and Tbx 18mRNA in the transfected groups. Scale bar=200 $\mu \mathrm{m}$. ${ }^{*} \mathrm{P}<0.05$ vs. GFP group. Tbx18, T-box 18; ISL-1, insulin gene enhancer binding protein 1; ADSCs, adipose tissue-derived stem cells; MOI, multiplicity of infection; GFP, green fluorescent protein.

float. This phenomenon was more apparent at an MOI of 100. With the increase in MOI values, the cell toxicity increased gradually. Thus, the MOI values of 50 (ISL-1) and 80 (Tbx18) were considered optimal and were adopted in the subsequent experiments. Under fluorescence microscopy, continuous expression of the viral genes was observed within 7 days. The mRNA expression of ISL- 1 and Tbx18 in the ISL-1+Tbx 18 group was significantly higher compared with the green fluorescent protein (GFP) group at day 7 after transfection (Fig. 1E). These results indicated that ISL-1 and Tbx 18 were stably overexpressed in ADSCs.

Expression analysis of associated cardiac genes. To evaluate the role of ISL- 1 and Tbx18 in the differentiation of the
SAN, the expression statuses of genes that are known to be important for the formation and function of the SAN were investigated. The genes detected in the present study include $\mathrm{HCN} 4, \mathrm{Cx} 45, \mathrm{Cx} 43$, homeobox protein Nkx-2.5 (Nkx2.5), Tbx 3 and cTnT. As indicated in Fig. 2A, the mRNA expression levels of HCN4, Cx45, Tbx3 and cTnT were significantly increased in the ISL-1, Tbx 18 and ISL-1+Tbx 18 group when compared with the GFP group $(\mathrm{P}<0.05)$. Conversely, the mRNA levels of $\mathrm{Cx} 43$ and Nkx2.5 were significantly downregulated in the ISL-1, Tbx18 and ISL-1+Tbx18 group when compared with the GFP group $(\mathrm{P}<0.05)$. In particular, the expression of genes in the ISL-1+Tbx18 group was significantly altered in a manner that promoted the differentiation of ADSCs into SAN-like cells compared with the GFP group 

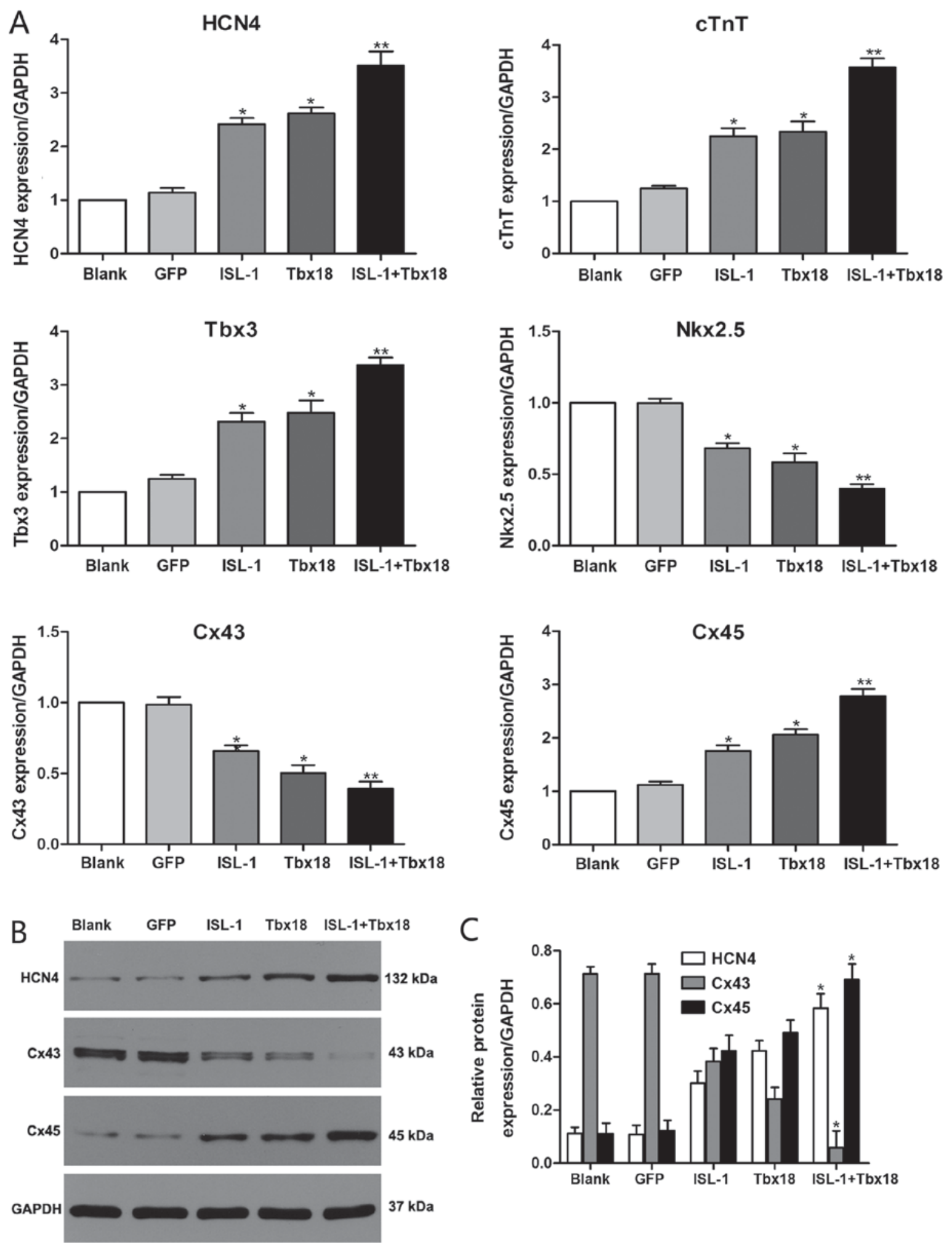

Figure 2. Expression of associated genes by RT-qPCR and western blotting after co-culture for 7 days. (A) HCN4, cTnT, Tbx3, Nkx2.5, Cx43 and Cx45 gene expression was examined using RT-qPCR. (B) HCN4, Cx43 and Cx45 protein expression examined using western blotting. (C) Quantitative assessment of HCN4, Cx43 and Cx45 protein levels by integrated optical density analyses. Similar results were obtained in three independent experiments. GAPDH was used as the protein control. "P $<0.05$ and ${ }^{* *} \mathrm{P}<0.01$ vs. GFP group. $\mathrm{HCN} 4$, hyperpolarization-activated cyclic nucleotide-gated cation channel 4; cTnT, cardiac troponin T; Tbx3, T-box 3; Nkx2.5, homeobox protein Nkx-2.5; Cx45, connexin 45; Cx43, connexin 43; GFP, green fluorescent protein; Tbx 18, T-box 18; ISL-1, insulin gene enhancer binding protein 1; RT-qPCR, reverse transcription-quantitative polymerase chain reaction

$(\mathrm{P}<0.01)$. Furthermore, the protein levels of HCN4, Cx43 and $\mathrm{Cx} 45$ were also examined by western blotting (Fig. 2B and $\mathrm{C}$ ). The results were identified to be consistent with those from the RT-qPCR assay.
Combined use of ISL-1+Tbx18 upregulates cardiac marker expression. To evaluate the role of the combination of ISL-1+Tbx18 in promoting the differentiation of ADSCs into SAN-like cells, cTnT, a myocardial specific marker, 


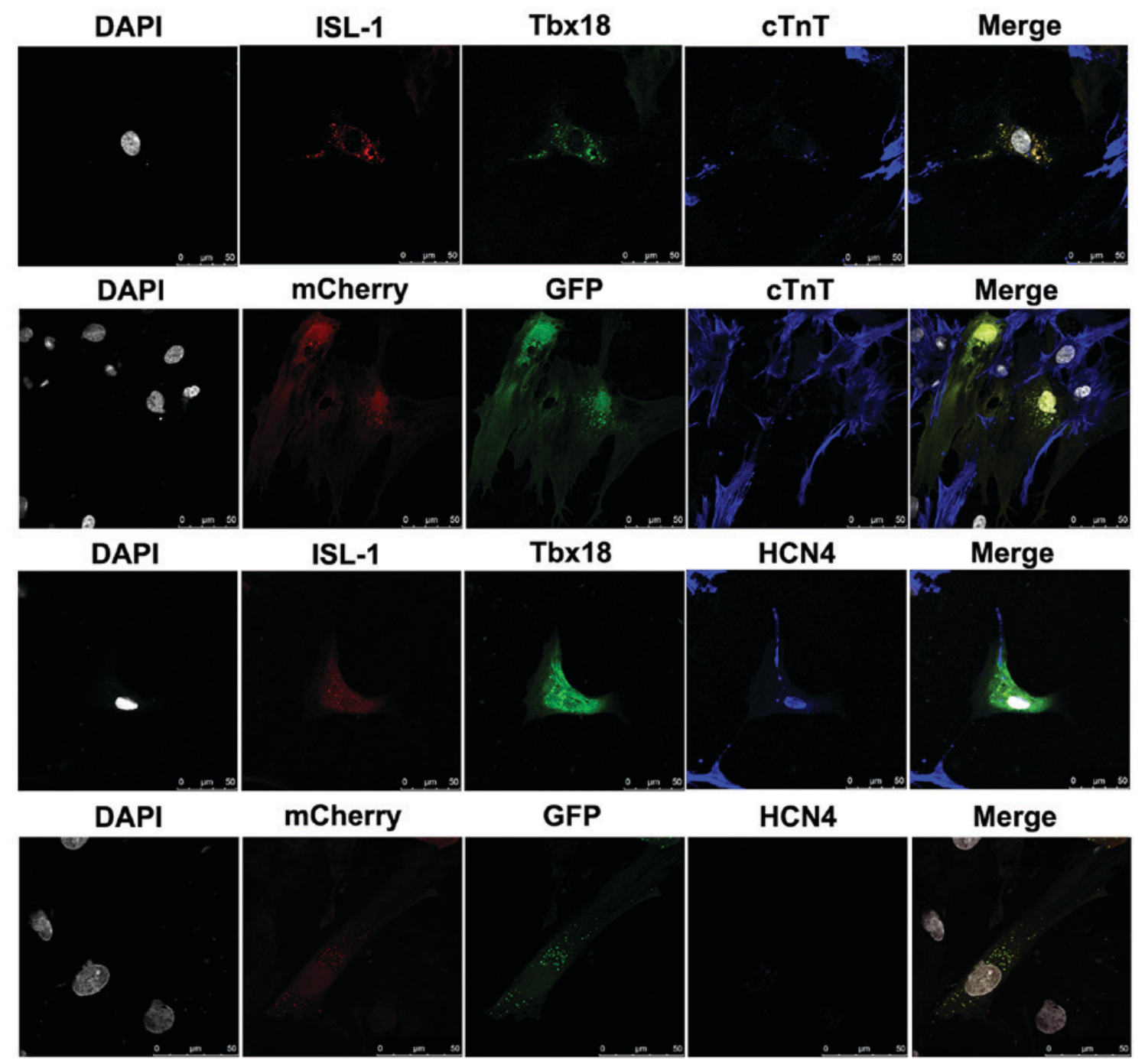

Figure 3. Cardiac-specific proteins examined by immunofluorescence staining in differentiated ADSCs after co-culture for 7 days (magnification, $\mathrm{x} 400$ ). Grey, nuclei stained with DAPI; red, ISL-1-ADSCs; green, Tbx18-ADSCs; and blue, representative positive staining of HCN4 and cTnT. ADSCs, adipose tissue-derived stem cells; Tbx18, T-box 18; ISL-1, insulin gene enhancer binding protein 1; HCN4, hyperpolarization-activated cyclic nucleotide-gated cation channel; cTnT, cardiac troponin T. Scale bar, $50 \mu \mathrm{m}$.

and HCN4, a marker of SAN function, were detected by immunofluorescence after co-culture for 7 days. ADSCs were randomly distributed in the culture and had formed connections with NRVMs. As demonstrated in Fig. 3, the immunofluorescent staining results revealed that the NRVMs and ADSCs transfected with ISL-1+Tbx 18 were positive for cTnT expression. However, the cTnT was barely detectable in ADSCs transfected with GFP. Meanwhile, ADSCs transfected with ISL-1+Tbx18 exhibited abundant positive staining for HCN4 proteins. However, HCN4 protein expression was barely detectable in the GFP group. ADSCs transfected with ISL-1+Tbx18 also exhibited a high percentage of HCN4 and cTnT compared with cells of the GFP group.

Combined use of ISL-1+Tbx18 improves ADSC automaticity. The intracellular electrical activity of spindle-shaped fluorescent cells was detected via the patch clamp technique (Fig. 4A). The $\mathrm{I}_{\mathrm{f}}$, a key contributor to spontaneous phase 4 depolarization, was recorded in ISL-1, Tbx18 and
ISL-1+Tbx18 groups. $\mathrm{I}_{\mathrm{f}}$ in a single beat had a greater inward current in the ISL-1+Tbx 18 group compared with ISL-1 group and Tbx18 group (Fig. 4B-D). The $\mathrm{I}_{\mathrm{f}}$ current is sensitive to $\mathrm{CsCl}$, and was therefore inhibited following the addition of $4 \mathrm{mmol} / 1$ of $\mathrm{CsCl}$ to the extracellular fluid (Fig. 4E), thus proving that ADSCs successfully generated $\mathrm{I}_{\mathrm{f}}$. In addition, the inward current resumed when the $\mathrm{CsCl}$ was eluted from the extracellular fluid. The Hyperpolarization-activated inward current was activated by the hyperpolarizing steps, ranging from $-40 \mathrm{mV}$ to $-140 \mathrm{mV}$, and had clear dependent characteristics of voltage (Fig. 4F).

\section{Discussion}

The SAN is a complex structure whose development is regulated by multiple factors. In recent years, researchers have aimed to introduce specific genes (19-21) and transplant pacemaker cells (22-24) into tissues with a damaged autonomic rhythm or conduction system in order to repair or replace them. Ideal pacemakers, either biological or electronic, respond to 


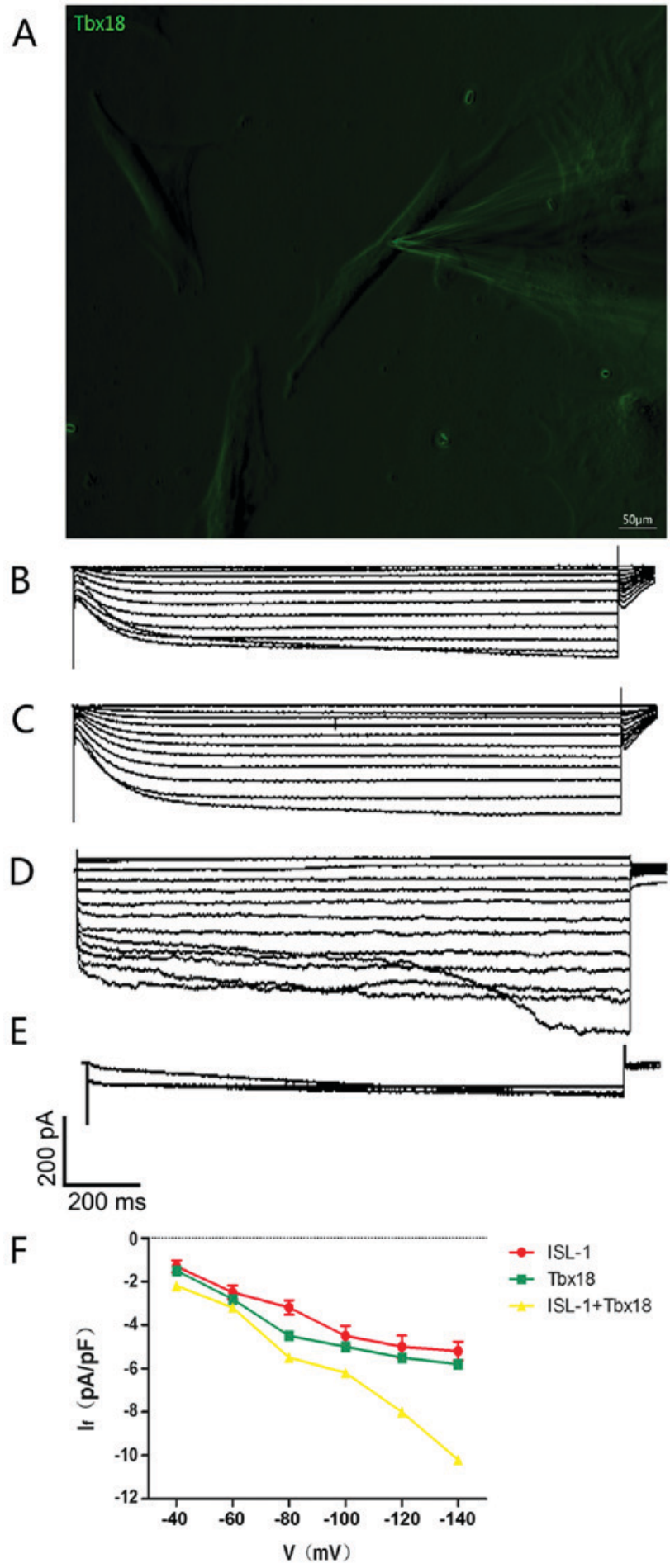

Figure 4. Single-cell electrophysiology of ADSCs. (A) Spindle-shaped cells were used for all electrophysiological recordings (magnification, x200) (B) Hyperpolarization-activated inward currents recorded from ISL-1-ADSCs using the patch clamp technique. (C) Hyperpolarization-activated inward currents recorded from Tbx18-ADSCs using the patch clamp technique. (D) Hyperpolarization-activated inward currents recorded from ISL-1+Tbx18-ADSCs using the patch clamp technique. (E) Hyperpolarization-activated inward currents $\left(\mathrm{I}_{\mathrm{f}}\right)$ were blocked by $\mathrm{CsCl}$ ( $4 \mathrm{mmol} / \mathrm{l})$. (F) Current density-voltage association of ISL-1 (red, $\mathrm{n}=6)$, Tbx 18 (green, $\mathrm{n}=6$ ) and ISL-1+Tbx18 (yellow, $\mathrm{n}=6$ ) groups. Tbx18, T-box 18; ISL-1, insulin gene enhancer binding protein 1; ADSCs, adipose tissue-derived stem cells; $\mathrm{I}_{\mathrm{f}}$, funny current. Scale bar, $50 \mu \mathrm{m}$.

the complex interactions between autonomic regulation and physical activity. To the best of our knowledge, no study on biological pacemaker therapy (gene- or cell-based) has achieved the target of transforming stem cells or other cells into pacemaker cells completely. A limiting step in developing a biological pacemaker is the overall efficiency of differentiating cells into pacemaker cells. Thus, it is important to find more effective methods to build biological pacemakers. There is a small area of Tbx 18/ISL-1 co-expression at the right lateral side of the inflow tract. This area exhibits expression of the SAN-specific gene Tbx3, but does not express Nkx2.5 $(12,13)$. This suggests that the co-expression of ISL- 1 and Tbx18 coincides with the formation of the SAN in terms of temporal and spatial expression. These important characteristics formed the basis of the current study.

In the present study, ADSCs were successfully transformed into spontaneously beating cells that exhibited behavior similar to that of pacemaker cells. The combination of ISL-1 and Tbx 18 resulted in a higher differentiation efficiency compared with transfections of a single transcription factor. The following lines of evidence support this result: i) Transduced cells exhibited the distinctive morphology of pacemaker-like cells; ii) characteristic mRNA alterations, including upregulation of HCN4, Tbx3, Cx45 and cTnT, and suppression of $\mathrm{Cx} 43$ and $\mathrm{Nkx} 2.5$; iii) characteristic protein modifications, including upregulation of HCN4 and Cx45, and suppression of $\mathrm{Cx} 43$; iv) the location of HCN4 and cTnT expression as identified by immunofluorescence; v) the $\mathrm{I}_{\mathrm{f}}$ recorded in ISL-1-and Tbx18-transduced cells. The present study not only confirmed the ability of combined ISL-1 and Tbx18 to convert ADSCs into pacemaker-like cells, but also investigated the physiological relevance of this conversion. To the best of our knowledge, this was the first study to combine ISL-1 and Tbx18 transfection in stem cells. The results indicated that co-expression of ISL-1 and Tbx 18 may significantly improve the number and quality of ADSCs differentiating into pacemaker-like cells, and may allow the construction of a new and stable biological pacemaker in vitro.

Nevertheless, the current study has a number of limitations. In this experiment, lentiviruses were selected as vectors, and these are known to integrate into the genome of the host. Moreover, screenings of stable cell lines or long-term observations were not performed. Due to the low efficiency of lentivirus transfection, no further animal experiments were performed. Compared with the degree of overexpression of exogenous genes, the mRNA expression levels of associated genes were not high in this experiment., which presumably was due to differences in species.

In previous years, researchers attempted to reprogram adult mammalian fibroblasts into embryonic-like cells via exposure to genetic transcription factors (25-27). Induced pluripotent stem cells (iPSCs) have great potential for differentiation into cells of ventricular, atrial and nodal cell lineages, and may avoid the limitations of immunosuppression and tumor formation (28). These characteristics give iPSCs the capacity for superior integration into host cardiac tissue in comparison to transplantation with adult tissue stem cells. The aim of the current study was to use iPSCs to create a biological pacemaker. There are numerous factors involved in the embryonic development of the SAN, and further research is required to determine whether there is a more effective method than the 
one described here. It also remains to be investigated whether the combination of ISL-1 and Tbx18 creates stable biological pacemaker activity in vivo, in addition to examining whether better combinations are available. This may help assessing the safety and validity of this method prior to its application in patients with SAN dysfunction.

\section{Acknowledgements}

The authors are grateful to Wuhan University School of Basic Medical Science and the Medical Research Center for Structural Biology for their assistance in conducting the experiments on the fluorescent images.

\section{Funding}

This study was supported by the Fundamental Research Funds for the Central Universities of China (grant no. 2042015kf0229).

\section{Availability of data and materials}

All data generated and analyzed during this study are included in this published article.

\section{Authors' contributions}

JZ and $\mathrm{CH}$ conceived and designed the study. JZ performed the experiments and wrote the paper. $\mathrm{CH}$ revised the manuscript and gave final approval of the version to be published. All authors read and approved the manuscript.

\section{Ethics approval and consent to participate}

Experimental procedures were conducted in accordance with the Institutional Guidelines for the Care and Use of Laboratory Animals at Wuhan University (Wuhan, China) and conformed to the NIH Guide for the Care and Use of Laboratory Animals (NIH Publications, no. 8023, revised 1978; Bethesda, MD, USA). The present study was approved by the Experimental Animal Committee of Wuhan University (no. WDRM20171015; Wuhan, China).

\section{Patient consent for publication}

Not applicable.

\section{Competing interests}

The authors declare that they have no competing interests.

\section{References}

1. Cho HC and Marbán E: Biological therapies for cardiac arrhythmias: Can genes and cells replace drugs and devices? Circ Res 106: 674-685, 2010.

2. Boink GJ, Christoffels VM, Robinson RB and Tan HL: The past, present, and future of pacemaker therapies. Trends Cardiovasc Med 25: 661-673, 2015.

3. Cingolani E, Goldhaber JI and Marbán E: Next-generation pacemakers: From small devices to biological pacemakers. Nat Rev Cardiol 15: 139-150, 2018.
4. Ionta V, Liang W, Kim EH, Rafie R, Giacomello A, Marbán E and Cho HC: SHOX2 overexpression favors differentiation of embryonic stem cells into cardiac pacemaker cells, improving biological pacing ability. Stem Cell Reports 4: 129-142, 2015.

5. Saito Y, Nakamura K, Yoshida M, Sugiyama H, Ohe T, Kurokawa J, Furukawa T, Takano M, Nagase S, Morita H, et al: Enhancement of spontaneous activity by $\mathrm{HCN} 4$ overexpression in mouse embryonic stem cell-derived cardiomyocytes-a possible biological pacemaker. PLoS One 10: e0138193, 2015.

6. Yang M, Zhang GG, Wang T, Wang X, Tang YH, Huang H, Barajas-Martinez H, Hu D and Huang CX: TBX18 gene induces adipose-derived stem cells to differentiate into pacemaker-like cells in the myocardial microenvironment. Int J Mol Med 38: 1403-1410, 2016.

7. Dmitrieva RI, Minullina IR, Bilibina AA, Tarasova OV, Anisimov SV and Zaritskey AY: Bone marrow- and subcutaneous adipose tissue-derived mesenchymal stem cells: Differences and similarities. Cell Cycle 11: 377-383, 2012.

8. Joo HJ, Kim JH and Hong SJ: Adipose tissue-derived stem cells for myocardial regeneration. Korean Circ J 47: 151-159, 2017.

9. Wiese C, Grieskamp T, Airik R, Mommersteeg MT, Gardiwal A, de Gier-de Vries C, Schuster-Gossler K, Moorman AF, Kispert A and Christoffels VM: Formation of the sinus node head and differentiation of sinus node myocardium are independently regulated by Tbx18 and Tbx3. Circ Res 104: 388-397, 2009.

10. Colombo S, de Sena-Tomás C, George V, Werdich AA, Kapur S, MacRae CA and Targoff KL: Nkx genes establish second heart field cardiomyocyte progenitors at the arterial pole and pattern the venous pole through Isl1 repression. Development 145, 2018.

11. Blaschke RJ, Hahurij ND, Kuijper S, Just S, Wisse LJ, Deissler K, Maxelon T, Anastassiadis K, Spitzer J, Hardt SE, et al: Targeted mutation reveals essential functions of the homeodomain transcription factor Shox 2 in sinoatrial and pacemaking development. Circulation 115: 1830-1838, 2007.

12. Christoffels VM, Mommersteeg MT, Trowe MO, Prall OW, de Gier-de Vries C, Soufan AT, Bussen M, Schuster-Gossler K, Harvey RP, Moorman AF, et al: Formation of the venous pole of the heart from an $\mathrm{Nkx} 2-5$-negative precursor population requires Tbx18. Circ Res 98: 1555-1563, 2006.

13. Mommersteeg MT, Domínguez JN, Wiese C, Norden J, de Gier-de Vries C, Burch JB, Kispert A, Brown NA, Moorman AF and Christoffels VM: The sinus venosus progenitors separate and diversify from the first and second heart fields early in development. Cardiovasc Res 87: 92-101, 2010.

14. Lopez MJ and Spencer ND: In vitro adult rat adipose tissue-derived stromal cell isolation and differentiation. Methods Mol Biol 702: 37-46, 2011.

15. Lokuta A, Kirby MS, Gaa ST, Lederer WJ and Rogers TB: On establishing primary cultures of neonatal rat ventricular myocytes for analysis over long periods. J Cardiovasc Electrophysiol 5: 50-62, 1994.

16. Zhu Y, Liu T, Song K, Ning R, Ma X and Cui Z: ADSCs differentiated into cardiomyocytes in cardiac microenvironment. Mol Cell Biochem 324: 117-129, 2009.

17. Choi YS, Dusting GJ, Stubbs S, Arunothayaraj S, Han XL, Collas P, Morrison WA and Dilley RJ: Differentiation of human adipose-derived stem cells into beating cardiomyocytes. J Cell Mol Med 14: 878-889, 2010.

18. Livak KJ and Schmittgen TD: Analysis of relative gene expression data using real-time quantitative PCR and the 2(-Delta Delta C(T)) method. Methods 25: 402-408, 2001.

19. Miake J, Marbán E and Nuss HB: Biological pacemaker created by gene transfer. Nature 419: 132-133, 2002.

20. Bucchi A, Plotnikov AN, Shlapakova I, Danilo P Jr, Kryukova Y, Qu J, Lu Z, Liu H, Pan Z, Potapova I, et al: Wild-type and mutant $\mathrm{HCN}$ channels in a tandem biological-electronic cardiac pacemaker. Circulation 114: 992-999, 2006.

21. Boink GJ, Nearing BD, Shlapakova IN, Duan L, Kryukova Y, Bobkov Y, Tan HL, Cohen IS, Danilo P Jr, Robinson RB, et al: $\mathrm{Ca}(2+)$-stimulated adenylyl cyclase $\mathrm{AC} 1$ generates efficient biological pacing as single gene therapy and in combination with HCN2. Circulation 126: 528-536, 2012.

22. Ruhparwar A, Tebbenjohanns J, Niehaus M, Mengel M, Irtel T, Kofidis T, Pichlmaier AM and Haverich A: Transplanted fetal cardiomyocytes as cardiac pacemaker. Eur J Cardiothorac Surg 21: 853-857, 2002. 
23. Kehat I, Khimovich L, Caspi O, Gepstein A, Shofti R, Arbel G, Huber I, Satin J, Itskovitz-Eldor J and Gepstein L: Electromechanical integration of cardiomyocytes derived from human embryonic stem cells. Nat Biotechnol 22: 1282-1289, 2004.

24. Xue T, Cho HC, Akar FG, Tsang SY, Jones SP, Marbán E, Tomaselli GF and Li RA: Functional integration of electrically active cardiac derivatives from genetically engineered human embryonic stem cells with quiescent recipient ventricular cardiomyocytes: Insights into the development of cell-based pacemakers. Circulation 111: 11-20, 2005.

25. Takahashi K and Yamanaka S: Induction of pluripotent stem cells from mouse embryonic and adult fibroblast cultures by defined factors. Cell 126: 663-676, 2006.

26. Liu H, Zhu F, Yong J, Zhang P, Hou P, Li H, Jiang W, Cai J, Liu M, Cui K, et al: Generation of induced pluripotent stem cells from adult rhesus monkey fibroblasts. Cell Stem Cell 3: 587-590, 2008 .
27. Li W, Wei W, Zhu S, Zhu J, Shi Y, Lin T, Hao E, Hayek A, Deng H and Ding S: Generation of rat and human induced pluripotent stem cells by combining genetic reprogramming and chemical inhibitors. Cell Stem Cell 4: 16-19, 2009.

28. Zhang J, Wilson GF, Soerens AG, Koonce CH, Yu J, Palecek SP, Thomson JA and Kamp TJ: Functional cardiomyocytes derived from human induced pluripotent stem cells. Circ Res 104: e30-e41, 2009.

This work is licensed under a Creative Commons Attribution-NonCommercial-NoDerivatives 4.0 International (CC BY-NC-ND 4.0) License. 